\title{
OCKHAM COMENTADOR DE PORFÍRIO: SOBRE A METAFÍSICA NA QUERELA DOS UNIVERSAIS
}

\author{
Carlos Eduardo de Oliveira \\ Departamento de Filosofia, FFLCH/USP
}

\begin{abstract}
Resumo: Em sua Exposição da Isagoge, Guilherme de Ockham argumenta que as questões que Porfírio se recusa a responder logo no início de sua Introdução para as Categorias de Aristóteles pressupõem uma discussão metafísica cuja tese fundamental é a defesa da singularidade de tudo o que existe. Pretendemos mostrar que dessa tese metafísica seguem-se duas conclusões: a impossibilidade de qualquer existência extramental para o universal bem como a conclusão de que o universal é, fundamentalmente, um signo mental natural. Como veremos, nessa Exposição, essas conclusões prescindem tanto de qualquer discussão a respeito do fundamento ontológico da semelhança que nos permite ordenar indivíduos em gêneros e espécies, quanto de qualquer discussão a respeito do que fundamenta o caráter naturalmente comum do próprio signo universal.
\end{abstract}

Palavras-chave: Guilherme de Ockham, Isagoge, gêneros, espécies, querela dos universais.

Abstract: William of Ockham argues, in his Exposition of Porphyry'sIsagoge, that the questions whose answers Porphyry refuses to give at the beginning of his Introduction to Aristotle's Categories presuppose a metaphysical debate which holds as its starting point the thesis of the singularity of all the existents. I aim to show that two conclusions follow from such thesis: the impossibility of any extramental existence of universals and the defense of universals as basically natural mental signs. As will be seen, in that Exposition, those conclusions prescind from any discussion on the ontological foundations of the similitude which allows us to order individuals in genus and species, and from any discussion about the foundations of the naturally aggregative or common character of the universal signs.

Keywords: William of Ockham, Isagoge, genus, species, Problem of Universals. 
․․․

Revista

Ética e

Filosofia Política

Número XXI - Volume III - dezembro de 2018 eticaefilosofia.ufjf.emnuvens.com.br

ISSN: $1414-3917$

e-ISSN: $2448-2137$

\section{Abreviaturas para as citações das fontes primárias:}

EPhys. - Expositio in libros Physicorum Aristotelis [in Ockham 1985; 1985b];

EPor. $\quad-$ Expositio in Librum Porphyrii de Praedicabilibus [in Ockham 1978];

In Metaph. - Commentaria in XIIII Aristotelis Metaphysicorum [in Averrois 1562];

Ord. $\quad-$ Scriptum in Librum Primum Sententiarum (Ordinatio) [in Ockham 1970; 1979];

QPhys - Quaestiones in Libros Physicorum Aristotelis [in Ockham 1984];

Quodl. - Quodlibeta Septem [in Ockham 1980];

Rep. $\quad-$ Quaestiones in Librum quartum sententiarum (Reportatio) [in Ockham 1984b];

SL $\quad-$ Summa Logicae [in Ockham 1974]. 


\section{1.) O questionário de Porfírio como problema.}

Quando se põe a comentar o questionário de Porfírio proposto no início da Isagoge (o qual, segundo Boécio, versa sobre a natureza e a subsistência dos gêneros e das espécies), apesar de se valer da tradução boeciana ${ }^{1}$, Ockham não dá indicações claras de que também tenha se valido, em sua interpretação, do comentário de Boécio a respeito dessas questões ${ }^{2}$. Afinal, desde a paráfrase que faz delas, Ockham deixa entrever uma interpretação particular, o que pode ser percebido numa rápida comparação entre o questionário tal qual proposto por Porfírio e sua apresentação por Ockham:

Certamente me abstendo das mais altas questões, mas acrescentando moderadamente as mais simples, certamente me recusarei a falar em seguida, sobre os gêneros e as espécies, o seguinte: subsistem ou são postos em intelecções isoladas e nuas? Subsistentes, são corporais ou incorporais? Ainda, se postos separados dos sensíveis ou nos sensíveis, também sobre a constância deles. Com efeito, essa é uma tarefa altíssima e carece de maior investigação. Tentarei agora, porém, mostrar-te isto: como, provavelmente, os antigos (e, dentre eles, principalmente os Peripatéticos) trataram destes e do que foi proposto. (BOÉCIO 1906, Ed. 2a , p. 147: 14-16; 159: 3-9; 167: 21-23.) ${ }^{3}$.

Ockham reproduz essas questões assim:

Nesta parte, exclui de sua consideração algumas questões impertinentes para a lógica, dizendo que há de se abster das mais altas questões que não cabem ao lógico e que há de tratar de outras questões mais fáceis que cabem ao lógico. No entanto, enumera particularmente três questões das quais quer se abster, indicando, com isso, que o lógico deve se abster de questões a elas semelhantes. A primeira questão é: se o gênero e a espécie são subsistentes fora da alma ou são unicamente no intelecto. A segunda: são corporais ou incorpo-

\footnotetext{
${ }^{1}$ Cf. Ockham 1978, p. 23* [= Gal, G.; Gambatese, A.; Brown, S., "Introductio", §3: De fontibus Expositionis].

${ }^{2}$ Para além da disputa a respeito das diversas respostas possíveis para esse questionário, parece haver, desde Boécio, uma disputa tanto pela interpretação do sentido de cada uma das três questões quanto pela compreensão do problema que Porfírio defenderá não ser o caso de tratar. Diferentemente do que defendem muitos de seus comentadores contemporâneos (por exemplo, GILSON 1955, p. 98 ss.; LIBERA 1996, p. 129-132; 1999, p. 224), Boécio pode bem ter apresentado em seu comentário a sua interpretação do problema visado pelas questões sem, no entanto, tê-lo resolvido [cf. OLIVEIRA, C. E. DE. Recapitulando uma disputa medieval: Boécio comentador de Porfírio e a Querela dos Universais. Analytica (no prelo), cujas conclusões reproduziremos aqui]. Seja ou não esse o caso, Ockham não teve semelhante cuidado: sua interpretação do problema que move aquelas questões aparece no desenrolar-se de suas respostas. Para um resumo das posições assumidas pelos comentários contemporâneos a respeito da interpretação medieval dessas questões, veja-se PICHE 2005, p. 147 s.

3 ... altioribus quidem quaestionibus abstinens, simpliciores uero mediocriter coniectans. || Mox, inquit, de generibus ac speciebus illud quidem, siue subsistunt siue in solis nudisque intellectibus posita sunt siue subsistentia corporalia sunt na incorporalia et utrum separata a sensibilibus na in sensibilibus posita et circa ea constantia, dicere recusabo. Altissimum enim est huiusmodi negotium et maioris egens inquisitionis. || Illud uero quemadmodum de his ac de propositis probabiliter antiqui tractauerunt et horum maxime Peripatetici, tibi nunc temptabo monstrare.
} 
rais? A terceira: se forem incorporais, são separados dos sensíveis ou são nos próprios sensíveis? (OCKHAM 1978, p. 10, lin. 2-11; EPor. Prooem., § 2) .

Três são, então, as questões propostas por Porfírio segundo a tradução de Boécio: 1.) Os gêneros e as espécies subsistem ou são postos em intelecções isoladas e nuas? 2.) Subsistentes, são corporais ou incorporais? 3.) Se postos separados dos sensíveis ou nos sensíveis, são constantes? Na paráfrase de Ockham, as questões reaparecem assim: 1.) O gênero e a espécie são subsistentes fora da alma ou são unicamente no intelecto? 2.) São corporais ou incorporais? 3.) Se forem incorporais, são separados dos sensíveis ou são nos próprios sensíveis?

Em seu segundo comentário para a Isagoge, Boécio teria interpretado a primeira questão de Porfírio como um dilema entre a defesa da existência real dos gêneros e das espécies e a possibilidade de que eles não passariam de intelecções sem objeto, isto é, de intelecções que, em última instância, não se refeririam a nada de real (provavelmente por um erro daquilo que Boécio chama de "opinião" $)$ e que, consequentemente, nada mais seriam que intelecções falsas. Note-se que essa oposição não se dá exatamente entre algo que ou existiria fora do intelecto ou existiria apenas no intelecto e, portanto, poderia ser falso. Trata-se, antes, fundamentalmente da oposição entre algo que pode existir realmente (e, consequentemente, ser inteligido como tal) e algo que pode não passar de uma intelecção falsa.

\footnotetext{
${ }^{4}$ In ista parte aliquas quaestiones logicae impertinentes a sua consideratione excludit, dicens quod ab altioribus quaestionibus quae ad logicum non pertinent est abstinendum, et de aliis quaestionibus facilibus quae ad logicum pertinent est tractandum. Specialiter autem enumerat tres quaestiones a quibus vult abstinere, per hoc innuens quod logicus debet a consimilibus abstinere. Prima quaestio est ista: Utrum genus et species sint subsistentia extra animam, vel sint tantum in intellectu. Secunda: An sint corporalia vel incorporalia. Tertia : Si sint incorporalia, an sint separata a sensibilibus vel sint in ipsis sensibilibus. ${ }^{5}$ De fato, como uma breve recapitulação do erro que Boécio acredita ser superado pela posição de Alexandre, por ele assumida, Boécio escreve o seguinte: "com efeito, não dizemos que seja necessário ver como falsa e vazia toda intelecção que certamente se faz desde um sujeito, ainda que não do modo pelo qual esse sujeito se dá para si mesmo. Com efeito, apenas naqueles que são feitos por composição há antes falsa opinião que inteligência. Com efeito, se alguém compor e unir pelo intelecto aquilo que não acontece de ser unido pela natureza, ninguém ignora que isso seja falso, como se alguém unisse, com a imaginação, o cavalo e o homem e elaborasse o Centauro." - non enim necesse esse dicimus omnem intellectum qui ex subiecto quidem fit, non tamen ut sese ipsum subiectum habet, falsum et uacuum uideri. in his enim solis falsa opinio ac non potius intellegentia est quae per compositionem fiunt. si enim quis componat atque coniungat intellectu id quod natura iungi non patitur, illud falsum esse nullus ignorat, ut si quis equum atque hominem iungat imaginatione atque effigiet Centaurum. (BOECIO 1906, Ed. 2a, cap. 11, p. 164, lin. 5-12).
} 
O dilema proposto por Ockham resgata em suas linhas gerais os mesmos aspectos da dificuldade levantada por Boécio. No entanto, em vez da oposição "ou tratamos de coisas existentes e, portanto, verdadeiras (a saber, os gêneros e as espécies "subsistentes") ou tratamos de coisas inexistentes e, portanto, falsas (ou seja, de intelecções "isoladas e nuas")", Ockham põe diretamente em xeque o referente da intelecção. Mas nada está mais longe da intenção de Ockham do que o dilema: ou os gêneros e as espécies existem na realidade extramental ou os gêneros e as espécies existem apenas no intelecto. Aqui, a fim de entender a interpretação de Ockham dessa primeira questão, é preciso dar o devido peso à estratégia de reduzir todas as três questões a uma dificuldade fundamentalmente metafísica: as questões apenas serão enfrentadas depois de Ockham ter estabelecido dois princípios fundamentais, a saber, o de que tudo que existe é singular e o de que nada que existe fora da mente pode obedecer simultaneamente a esse princípio de singularidade e ao caráter de comunidade atribuído àquilo que é o universal.

Assumidos esses princípios, o problema da subsistência passa rapidamente a ser um problema de significação ${ }^{6}$. Uma vez concluído daquela discussão prévia que os gêneros e as espécies não são senão certas intelecções, Ockham reduz a pergunta sobre se o gênero e a espécie são subsistentes fora da alma ou são unicamente no intelecto ao problema daquilo que, fora da alma, é significado pelas intelecções do gênero e da espécie. Sendo intelecções, os gêneros e as espécies subsistem na alma. No entanto, o gênero e a espécie são intelecções do que subsiste fora da alma. Mas, uma vez que o gênero e a espécie não podem subsistir enquanto tais fora da alma, o que, então, fora da alma, é objeto dessas intelecções?

A segunda questão proposta por Porfírio aparece, mais uma vez na interpretação de Boécio, como um dilema a respeito do modo de subsistência dos gêneros e das espécies: uma vez que os gêneros e as espécies não podem se reduzir a intelecções falsas,

\footnotetext{
${ }^{6}$ Cf. BIARD 1997, p. 41: “Ce qu'on appellera ultérieurement, en un curieux français, le «problème des universaux » est un problème mal posé, voire un faux problème puisque les formulations porphyriennes portent sur de modes d'être là où il n'est question que de modes de signification. Au premier abord, il s'agit d'un problème étranger à la logique, plutôt de nature métaphysique, mais une juste conception du signe conceptuel dissout la difficulté en déplaçant la question. ...”. Há que se ter claro, porém, que não parece que Ockham tenha claramente tomado o questionário de Porfírio como sendo ele mesmo um problema mal posto. Antes, ele parece tomar esse questionário como a indicação feita por Porfírio a respeito dos problemas levantados pelos que fazem essa confusão entre a lógica e a metafísica.
} 
qual seria a subsistência daquilo que é inteligido: corporal ou incorporal? Abandonada a hipótese de que tratar de gêneros e espécies seria tratar de intelecções "isoladas e nuas", isto é, de intelecções vazias porque intelecções errôneas que, como resultado de seu erro, acabam tendo por objeto coisas inexistentes, restaria saber se os gêneros e as espécies subsistem na realidade que apreendemos por meio dos sentidos ou se subsistem incorporalmente tal qual as substâncias incorpóreas (nos exemplos de Boécio: Deus, a mente, a alma...) ou, ainda, se subsistem corporalmente apesar de serem, em si mesmos, incorpóreos, como é o caso de certas intelecções obtidas a partir daquilo que é sensível (mais uma vez, nos exemplos de Boécio, tal como a linha que é pensada abstraída da matéria ainda que, na realidade, a linha não exista senão em certa superfície material: na medida em que é considerada em si mesma, sem que se leve em conta sua ligação com a matéria, a linha é algo incorporal, uma intelecção, ainda que subsista apenas na medida em que é algo corpóreo - o contorno de certa superfície material).

Como descrevemos há pouco, ao desconsiderar, na primeira questão, a análise sobre a validade das intelecções, Ockham fez com que a problemática que, segundo Boécio, deveria ser abordada apenas na segunda questão, de certa forma, já tenha sido considerada no enfrentamento da primeira. Assim, para Ockham, a segunda questão visará apenas desfazer um possível mal-entendido na relação entre tipos diversos de signos. Quanto a isso, note-se primeiramente que, ao perguntar se os gêneros e as espécies são corporais ou incorporais, Ockham não propõe nada que se pareça a um dilema cuja solução seria óbvia: sendo intelecções, os gêneros e as espécies são corpóreos ou incorpóreos? O problema visado por Ockham é bem outro: há universais que subsistem na alma, as intelecções universais, e há universais que subsistem fora da alma - os universais por instituição, a saber, vozes (/palavras) tais como "homem", instituídas para significar a muitos. Obviamente, a voz universal (quer falada ou escrita) "homem", enquanto vozfalada ou escrita, é algo corporal. Donde a questão: os gêneros e as espécies, agora tomados explicitamente enquanto universais, são (/subsistem) corporalmente ou incorporalmente? Em outras palavras, tanto os signos convencionais impostos para significar o universal como a intelecção universal têm o mesmo estatuto de existência? 


\section{Revista \\ Ética e \\ Filosofia Política}

Número XXI - Volume III - dezembro de 2018

eticaefilosofia.ufjf.emnuvens.com.br

ISSN: $1414-3917$

e-ISSN: 2448-2137

Por fim, a terceira questão de Porfírio é interpretada por Boécio como o problema que se seguiria das opções tomadas como respostas para as questões anteriores. Na primeira questão, teríamos a resposta de que o gênero e a espécie têm de ser coisas verdadeiras, ou seja, de que a discussão sobre os gêneros e as espécies não se reduz a um discurso falso ou vazio. Tratando-se de coisas verdadeiras e, portanto, existentes de algum modo, os gêneros e as espécies não poderiam ser coisas corporais na medida em que "gênero" e "espécie" são nomes que designam algo comum a uma série de indivíduos. Mas, ainda assim, há uma diferença entre a natureza e a subsistência de algo. Há coisas que são corpóreas e subsistem corporalmente: esse é o caso de todas as coisas sensíveis. Há, ainda, coisas que são incorpóreas e subsistem incorporalmente, tal é o caso de Deus. Por fim, há coisas que são incorpóreas quanto à natureza, mas que apenas subsistem corporalmente: é o caso da linha, incorpórea quanto à sua natureza intelectual, corpórea quanto ao fato de que apenas subsiste enquanto unida a um corpo. Portanto, se o universal não pode subsistir corporalmente uma vez que tudo que é corpóreo é singular, resta que ele seja incorpóreo ao menos quanto à sua natureza. Aqui entra a pergunta a respeito da "constância" dos gêneros e das espécies: sendo intelecções incorpóreas universais, como os gêneros e as espécies podem se referir a indivíduos corpóreos singulares? Há "constância" entre a natureza incorpórea dos universais e sua subsistência corpórea nos singulares? Em outras palavras, como é possível sustentar que a intelecção de algo cuja característica fundamental é a universalidade possa, de algum modo, ser dita a intelecção daquilo que, em sua realidade corpórea, é completamente refratário à universalidade porque singular?

Em Ockham, se a segunda questão propôs uma análise da relação entre os universais "naturais" (as intelecções) e "convencionais" (as vozes) quando relacionados à sua subsistência, a terceira propõe como se dá a relação entre as intelecções universais e as coisas por elas significadas: sendo intelecções, de que modo são intelecções de coisas exteriores à alma? Trata-se, assim, de uma espécie de "inversão" do interesse da primeira questão. Se na primeira o interesse era saber o que, fora da alma, é significado pela intelecção, agora a pergunta procura saber de que modo a intelecção mantém uma relação com seu objeto. 
Em suma, a semelhança inicialmente visada se dissolve em diferenças fundamentais entre a interpretação ockhamiana e a de Boécio. Se Boécio arma sua exposição de modo que ela só possa ser teoricamente compreensível e consistente se unida à certa teoria da abstração, em Ockham a exposição é montada de modo a mostrar que o fundamento do universal não é nada mais que uma relação entre signos e significados. Se para Boécio a base para a compreensão do problema levantado pelo questionário porfiriano reside em certa teoria da abstração enquanto sua solução provavelmente estaria no resultado de certa disputa entre o aristotelismo e o platonismo ${ }^{7}$, para Ockham, enquanto a base para a solução dessa disputa gira em torno de certa teoria da significação, a compreensãodo problema visado por esse questionário apenas pode ser creditada aos pres$\operatorname{supostos}^{8}$ de determinada metafísica: a metafísica do singular.

\section{2.) As questões de Porfírio e a metafísica do singular.}

Logo após ter recitado, a seu modo, o elenco das questões levantadas pelo questionário de Porfírio, Ockham interpreta a recusa porfiriana de tratar "das mais altas questões" como a recusa de abordar, num texto de lógica, uma discussão metafísica. Na sequência, assim como faz Boécio, anuncia a opção de não seguir fielmente a Porfírio nessa proposta particular. Mas, diferentemente do que se passa no comentário boeciano, em que, mais do que oferecer uma resolução, a intenção é “esclarecer” o problema le-

\footnotetext{
7 “Mas Platão sustenta que os gêneros, as espécies e outros não são apenas inteligidos como universais, mas que também é verdade que subsistem para além dos corpos. Aristóteles, porém, certamente sustenta que são inteligidos como incorporais e universais, mas que subsistem nos sensíveis. Não avancei a ponto de estar apto a julgar as posições deles,com efeito, isso cabe ao que há de mais alto na filosofia. De fato, por isto seguimos mais cuidadosamente a posição de Aristóteles: não porque, antes de tudo, a aceitamos, mas porque este livro se restringe aos Predicamentos, dos quais Aristóteles é o autor." - sed Plato genera et species non modo intellegi uniuersalia, uerum etiam esse atque praeter corpora subsistere putat, Aristoteles uero intellegi quidem incorporalia atque uniuersalia, sed subsistere in sensibilibus putat; quorum diiudicare sententias aptum esse non duxi, altioris enim est philosophiae. Idcirco uero studiosius Aristoelis executis sumus, non quod eam maxime probaremus, sed quod hic liber ad Praedicamenta conscriptus est, quorum Aristoteles est auctor. (BOÉCIO 1906, Ed. 2a , p. 167, lin. 12-20. Grifo nosso.).

${ }^{8}$ Portanto, proporemos aqui que, no texto da E.Por. de Ockham, temos claramente a defesa de uma tese inversa daquela que é tomada por Michon (1994, p. 483) como base para a sua interpretação da filosofia de Ockham, ainda que não venhamos a expressar aqui qualquer juízo sobre aquilo que ele entende como a consequência imediata de sua opção: “... A contrapartida positiva, a afirmação de que toda realidade é singular (particularismo ontológico), foi apresentada [sc. por Michon em seu livro] como uma conclusão e não como uma premissa. Se for uma premissa, então, todos os argumentos que reportamos e todos os que foram esquecidos, em favor do particularismo e contra o realismo dos universais, são inúteis...”.
} 
vantado pelas questões - o "nó da dúvida"9 -, Ockham propõe-se efetivamente a respondê-las. A motivação, ainda que ela também diversa da de Boécio, continua sendo propedêutica. Por desconhecer a discussão metafísica, muitos "modernos" teriam cometido muitos erros em lógica:

Diz querer se abster delas e de outras. Ora, a causa pela qual há de se abster delas é: porque essas questões cabem ao metafísico e carecem de uma discussão cuidadosa, que não deve ser feita neste livro. Há, porém, que se sustentar sobre os já mencionados universais alguns ditos dos antigos que cabem ao lógico e, maximamente no presente opúsculo, há que se sustentar os ditos dos Peripatéticos. No entanto, por mais que as questões mencionadas e as semelhantes a elas não caibam ao lógico, mas ao metafísico, há, porém, que se dizer brevemente (uma vez que delas se tratou mais extensamente noutro lugar) o que há de ser sustentado sobre elas segundo a sentença de Aristóteles e segundo a verdade, uma vez que, por ignorá-las, muitos modernos cometeram vários erros inclusive quanto à lógica. (OCKHAM 1978, p. 10 s., lin. 11-23; EPor. Prooem., § 2) $)^{10}$.

O que se segue dessa recapitulação é, como diz o próprio texto que acabamos de ver, um resumo do que Ockham teria apresentado noutro lugar. De fato, Ockham trata em ao menos duas outras oportunidades mais extensamente sobre o tema dos universais ${ }^{11}$, mas a EPor. retoma argumentos da Ordinatio que não se repetem na Suma de

\footnotetext{
${ }^{9}$ Cf. BoÉCIO 1906, Ed. 2a, p. 161, lin. 8-14: “Embora seja árduo resolver, enquanto o próprio Porfírio recusa, as questões que, no entanto, enfrentarei - de modo a não deixar atribulada a alma do leitor e não gastar eu mesmo tempo e trabalho naqueles que estão além do encadeamento do encargo assumido -, primeiro, certamente relatarei algo da dificuldade relativa à questão, depois, tentarei desatar e explicar o próprio nó da dúvida." - quas licet quaestiones arduum sit ipso interim Porphyrio renuente dissoluere, tamen adgrediar, ut nec anxium lectoris animum relinquam nee ipse in his quae praeter muneris suscepti seriem sunt, tempus operamque consumam. primum quidem pauca sub quaestionis ambiguitate proponam, post uero eundem dubitationis nodum absoluere atque explicare temptabo. e, supra, nota 7.

${ }^{10}$ Ab istis et ab aliis dicit se velle abstinere. Causa autem quare est ab istis abstinendum est ista, quia istae quaestiones pertinent ad metaphysicum et indigent subtili discussione, quod non est in isto libello faciendum; sed aliqua dicta antiquorum de praedictis universalibus, quae ad logicum pertinent, et maxime dicta Peripateticorum, in praesenti opusculo sunt ponenda. Quamvis praedictae quaestiones et consimiles non ad logicum sed ad metaphysicum sint pertinentes, quia tamen ex ignorantia earum multi moderni in multiplices errores etiam in logica sunt prolapsi, ideo de ipsis breviter quid sit secundum sententiam Aristotelis et secundum veritatem tenendum, est dicendum, quia de eis alibi est diffusius tractatum.

${ }^{11}$ Como aponta a própria edição latina da qual retiramos esse texto, Ockham teria tratado mais extensamente dos universais tanto em Ord. I, d. 2, q. 4-8 (OTh. II, p. 99-292) como em sua Suma de Lógica, parteI, cap. 14-25 (OPh. I, p. 47-84). De acordo com a datação proposta por Spade (1999, "Introduction", p. 5-8), tanto a Ordinatio (1318) quanto a Suma Lógica (1323) podem ser os textos referidos por Ockham na Exposição da Isagoge (composta junto das exposições das Categorias, do Perihermenias e do Tratado da Predestinação entre 1321-1324). Segundo Andrés (1969, p. 60-65), o texto da Suma de Lógica apresenta de uma forma mais resumida a discussão da Ordinatio, mas preserva as mesmas conclusões.
} 
Lógica. Nessa apresentação "abreviada" da exposição do texto de Porfírio, Ockham principia sua discussão anunciando que ela girará em torno de duas conclusões:

a.) "Qualquer coisa existente imaginável é, desde si, sem qualquer adição, uma coisa singular e numericamente uma de modo que nenhuma coisa imaginável é singular por algo acrescentado a ela."12,

b.) "Não há um universal existente realmente fora da alma nas substâncias individuais, nem desde a substância ou desde a essência delas. Ora, o universal ou é unicamente na alma ou é universal por instituição, do modo pelo qual a voz falada 'animal' (e, de modo semelhante, 'homem') é universal: porque é predicável a muitos; não por si, mas pelas coisas que significa." $"$.

A primeira será apresentada como uma tese geral a respeito da singularidade do existente, isto é, a defesa de que tudo o que existe é singular. A segunda será apresentada como se a implicação do que é defendido pela tese anterior na compreensão de certos argumentos de autoridade. Chama a atenção no desenvolvimento da argumentação dessas conclusões o fato de que, na construção da primeira, há uma atenção especial para a apresentação das justificativas do que é defendido, enquanto na segunda não há muito mais do que uma recitação na qual não são dadas maiores justificativas para as conclusões assumidas. A discussão "racional" da primeira conclusão aparece, assim, como fundamentação suficiente para a declaração da "intenção" das autoridades.

a.)Toda coisa existente imaginável é, desde si, sem qualquer adição, uma coisa singular e numericamente uma:

\footnotetext{
12 Cf. OCKHAM 1978, p. 11, lin. 24-28; EPor. Prooem., § 2: “Ora, deve ser indubitavelmente assumido que qualquer coisa existente imaginável é, desde si, sem qualquer adição, uma coisa singular e numericamente uma de modo que nenhuma coisa imaginável é singular por algo acrescentado a ela. Ora, esta é uma afecção que convém imediatamente a qualquer coisa, porque toda coisa por si ou é ela mesma ou é diversa de outra." - Est autem tenendum indubitanter quod quaelibet res imaginabilis exsistens est de se, sine omni addito, res singularis et una numero, ita quod nulla res imaginabilis est per aliquid additum si bi singularis ; sed ista est passio conveniens immediate amni rei, quia omnis res per se vel est eadem vel diversa ab alia.

${ }^{13}$ OCKHAM 1978, p. 11, 1. 29-34; EPor. Prooem., § 2: Secundo tenendum quod nullum universale est extra animam exsistens realiter in substantiis individuis, nec est de substantia vel essentia earum; sed universale vel est tantum in anima, vel est universale per institutionem quomodo haec vox prolata 'animai', et similiter 'homo', est universalis, quia de pluribus est praedicabilis, non pro se sed pro rebus quas significat.
} 
A maior parte do comentário é dedicada à exposição da primeira "conclusão", uma tese geral que Ockham propõe poder ser defendida tanto pela razão, ou seja, por argumentos que não são tomados exatamente como a reprodução daquilo que outros já defenderam na discussão desse assunto, quanto por aquilo que é encontrado nos textos das "autoridades": certas passagens da Metafísica de Aristóteles e dos comentários a elas propostos por Averróis. A prática serve principalmente como a enunciação do quadro conceitual segundo o qual Ockham crê que essas autoridades devem ser sustentadas.

A defesa "pela razão" visa os laços entre a existência e a singularidade. A tese, como sabemos, é: “qualquer coisa existente imaginável é, desde si, sem qualquer adição, uma coisa singular e numericamente uma, de modo que nenhuma coisa imaginável é singular por algo acrescentado a ela". Sem fazer qualquer menção ao caráter "imaginável"14 da coisa existente, Ockham contra argumenta: se uma coisa não for singular desde si, ela ou contém essencialmente várias coisas ou é precisamente uma coisa. Se contém essencialmente várias coisas, essas coisas ou têm um número limitado ou não. Uma coisa singular não pode conter essencialmente infinitas coisas em ato ${ }^{15}$. Logo, elas são em número limitado. Uma vez que, quanto a elas mesmas, cada uma dessas coisas essencialmente contidas é numericamente uma coisa, qualquer todo resultante delas será numericamente uma coisa. Por outro lado, se uma coisa não for singular desde si, mas também não contiver essencialmente várias coisas, então ela é precisamente uma coisa. Assim, contenha ou não essencialmente várias coisas, se for uma coisa existente, a coisa universal será numericamente uma e, consequentemente, singular.

\footnotetext{
14 A princípio, "imaginável", aqui, parece não querer dizer nada além da possibilidade de que a coisa existente seja, de algum modo, apreendida pelo intelecto. Por exemplo: "de outro modo, toma-se 'representar' por aquilo que, conhecido, outro é conhecido, assim como a imagem representa aquilo de que é [sc. imagem] pelo ato de recordar" - Aliter accipitur 'repraesentare' pro illo quo cognito aliquid aliud cognoscitur, sicut imago repraesentat illud cuius est per actum recordandi. (Ockham 1980, p. 310, 1.14 ss.; Quodl. IV, q. 3).

15 "pergunto sobre essas coisas incluídas essencialmente: ou são em um certo número, ou não. Não pode ser dito que não são em um certo número, porque então seriam infinitas em ato, o que é impossível. Se são em um certo número, então, qualquer uma delas é numericamente uma e, consequentemente, todo resultante será numericamente um." - quaero de ilis rebus inclusis essentialiter, aut sunt in certo numero aut non. Non potest dici quod non sunt in certo numero, quia tunc essent infinita in actu, quod est impossibile. Si sunt in certo numero, ergo quaelibet illarum est una numero, et per consequens totum resultans erit unum numero. (OCKHAM 1978, p. 11, lin. 39-43; EPor. Prooem., § 2).
} 


\section{Revista \\ Ética e \\ Filosofia Política}

Número XXI - Volume III - dezembro de 2018

eticaefilosofia.ufjf.emnuvens.com.br

ISSN: $1414-3917$

e-ISSN: $2448-2137$

Nessa argumentação, temos enunciados aqueles que serão os dois princípios básicos de toda a discussão a ser desenvolvida. Sumariamente, o primeiro deles é o de que é numericamente uma coisa (ou seja, singular) qualquer todo que contenha essencialmente várias coisas desde que não em número infinito. O segundo é o de que é precisamente numericamente uma coisa aquela que, mesmo não sendo singular desde si, não contém essencialmente várias coisas (pode-se considerar que o universal não seja singular desde si porque, desde si, o universal é comum a várias coisas...).

Insistindo um pouco mais nessa primeira argumentação, em suma, temos Ockham enunciando que, se for considerado uma coisa existente, o universal deve sempre ser tomado como uma coisa singular: tudo o que existe é singular, mesmo que contendo essencialmente vários ${ }^{16}$. Seja dado, aqui, o devido destaque à natureza do argumento desenvolvido. Tomado do ponto de vista da metafísica e não da lógica, o universal não é considerado como aquilo que pode ser predicado de muitos, mas como uma coisa existente. Ainda não está em questão, portanto, saber se esse universal é ou não idêntico ao próprio indivíduo, se ele é apenas uma intelecção ou, até mesmo, se ele é algo existente por si fora da mente. Importa somente a defesa de que, existindo, o universal terá de ser uma coisa singular. A consideração das várias coisas nele contidas essencialmente, por sua vez, não parece ser a consideração dos vários indivíduos aos quais ele pode ser predicado ou inerente, mas a consideração das várias coisas que definem determinado universal. Enquanto o definem, tais coisas estão em ato e não podem ser infinitas. Segue-se daí uma primeira conclusão a respeito do universal: mesmo que contenha essencialmente as várias coisas envolvidas em sua definição, o universal não é, desde si, várias coisas, mas é numericamente uma coisa, ou seja, é uma coisa singular.

Quanto à segunda posição assumida, Ockham argumenta o seguinte: se o universal e, por exemplo, Sócrates forem a mesma coisa, então, o universal é uma coisa singular, ou seja, não é nada além do próprio Sócrates. Mas, se o universal e Sócrates forem

\footnotetext{
${ }^{16} \mathrm{Na}$ interpretação de Moody (1935, p. 80): "The above argument is a dialectical proof of the indemonstrable metaphysical principle of the convertibility of ensand unum. Since it is a primary principle of first philosophy, it cannot be demonstrated from any principles prior to it. But it can be shown to be presupposed in all discourse, in the manner in which Aristotle proves dialectically, in the Metaphysics, that the law of non-contradiction is presupposed by any affirmation or denial."
} 
várias coisas, mas não infinitas, isto é, se eles forem coisas diferentes, mas num número finito, teremos então não mais do que duas coisas, o próprio Sócrates e o universal:

\begin{abstract}
Mas quando há unicamente duas coisas, cada uma delas é numericamente uma, portanto, esta coisa universal é numericamente uma e, consequentemente, é singular. Confirma-se, porque toda coisa que é uma coisa e não várias coisas é numericamente uma, com efeito, essa é a definição nominal daquilo que é numericamente um; ora, esta coisa universal é uma coisa e não várias, portanto, é numericamente uma coisa, portanto, é singular. (OCKHAM 1978, p. 12, lin. 54-59; EPor. Prooem., § 2) ${ }^{17}$.
\end{abstract}

Toda coisa distinta de outra é numericamente uma coisa, donde se segue nossa segunda conclusão: se o universal for uma coisa existente distinta de outras, não há alternativa senão tomá-lo como uma coisa singular. O próximo argumento insiste na relação do universal com várias coisas. Mas diferentemente do primeiro, no qual o universal era posto em relação com as várias coisas pertinentes à sua definição, agora a proposta será a de relacioná-lo com as várias coisas nas quais ele pode ser dito existir.

Aparentemente, a proposta analisada questionaria se não seria possível sustentar que o universal exista em várias coisas mesmo sendo diverso delas na medida em que, antes que a essas várias coisas enquanto coisas particulares, o universal deveria sua existência a uma essência comum a essas várias coisas particulares:

E não pode ser dito que esta coisa é universal ainda que não seja várias coisas porque é em vários e desde a essência de vários, assim como a humanidade ou o homem é em todos os homens e desde a essência de todos os homens: isso não vale porque tal coisa ou é variada, de modo que é uma e outra naquelas várias coisas, ou não é variada, de modo que não é uma e outra. Se for concedido o primeiro, então, necessariamente qualquer uma daquelas coisas é singular e, consequentemente, dado que não haja outra coisa além daquelas coisas, segue-se que qualquer coisa é singular. Se for concedido o segundo, ainda se tem o proposto, porque aquela coisa, por mais que seja em várias coisas, é verdadeiramente singular dado que é uma e não várias. (OCKHAM 1978, p. 12, lin. 60-69; EPor. Prooem., § 2) ${ }^{18}$.

\footnotetext{
17 Sed quando sunt tantum duae res, utraque illarum est una secundum numerum; ergo ista res universalis est una secundum numerum, et per consequens est singularis. Confirmatur, quia omnis res quae est una res et non plures res, est una numero; hoc enim est quid nominis istius quod est unum numero; sed ista res universalis est una res et non plures, ergo est una res numero, ergo est singularis.

${ }^{18} \mathrm{Nec}$ potest dici quod ista res est universalis quamvis non sit plures res, et hoc quia est in pluribus et de essentia plurium, sicut humanitas vel homo est in omnibus hominibus et de essentia omnium hominum. Hoc non valet, quia talis res aut est variata, ita quod est alia et alia in illis pluribus rebus, aut est invariata, ita quod non est alia et alia. Si detur primum, ergo necessario quaelibet illarum rerum est singularis, et per consequens, cum non sit alia res praeter illas res, sequitur quod quaelibet res est singularis. Si detur secundum, adhuc habetur propositum, quia ista res, quantumcumque sit in pluribus rebus, est vere singularis ex quo est una et non plures.
} 


\section{Revista \\ Ética e \\ Filosofia Política}

Número XXI - Volume III - dezembro de 2018

eticaefilosofia.ufjf.emnuvens.com.br

ISSN: 1414-3917

e-ISSN: $2448-2137$

Como resposta, vemos que algo não é dito universal porque é em vários $e$ desde a essência de vários, isto é, na medida em que existe nos vários indivíduos aos quais se refere $e$, de algum modo, existe em virtude da essência desses indivíduos. A tese que Ockham nega defenderia, portanto, que, de um lado, uma coisa é universal porque existe em vários indivíduos. Mas, de outro lado, a coisa universal mantém sua identidade, isto é, pode ser dita uma coisa universal diversa dos indivíduos nos quais ela existe, porque, de algum modo, a coisa universal existe enquanto é parte ou o mesmo que a essência desses vários nos quais existe: trata-se de uma sorte de "existência universal", tanto nos vários indivíduos quanto na essência una deles. Tentando reformular o argumento de um modo mais explícito, parece-nos que Ockham está defendendo que, quando dizemos que uma coisa é universal, devemos escapar da confusão de querer entender com isso que uma coisa existe universalmente: tanto nos indivíduos quanto na essência dos indivíduos. Ainda que uma coisa seja universal, ela apenas poderá existir como uma coisa singular.

Assim, se o universal for uma coisa variada nos indivíduos de modo a ser uma e outra coisa na medida em que é em um ou em outro indivíduo, então o universal será o mesmo que os próprios indivíduos - afinal, como acabamos de ver, "toda coisa distinta de outra é numericamente uma coisa”, ou seja, todo universal existente num indivíduo distinto do universal existente noutro indivíduo é numericamente uma coisa: a mesma coisa que o indivíduo no qual existe. Tantos serão os universais quantos forem os indivíduos; o universal não será nada além do próprio singular. Se, porém, o universal for tomado como uma única coisa ainda que existente em vários indivíduos, ainda assim ele será numericamente uma coisa. Mais uma vez, "toda coisa distinta de outra é numericamente uma coisa". Em suma, ou o universal é uma única coisa que existe em várias coisas ou, contido nas várias coisas nas quais existe, o universal não é senão o mesmo que cada uma delas.

A principal diferença entre o argumento final de Ockham e a posição inicialmente rejeitada é sutil: o universal existir tanto na essência das coisas singulares quanto em cada uma delas já não é o mesmo que a mesma coisa universal existir em vários singulares. A respeito desta nova posição, a dificuldade obviamente está em entender se é de 
algum modo possível que uma coisa se mantenha numericamente a mesma ainda que existindo em diversos. Segundo Ockham,

Isso fica claro com um exemplo. Por mais que a mesma matéria numericamente seja primeiro no ar e parte dele e, depois, no fogo e parte do fogo, porque, no entanto, não é uma e outra matéria, é uma matéria numericamente. Portanto, do mesmo modo, se esta humanidade que é posta no universal, por mais que seja em vários homens, se, no entanto, não for uma e outra, será verdadeiramente uma numericamente. De modo semelhante, segundo a intenção do Comentador, porque o intelecto em ti e em mim não é diverso, é, segundo ele, um numericamente, de modo que ser geralmente em diversos ou com diversos ou sob diversos não faz nada que não seja numericamente um enquanto não for um e outro; e, assim, toda coisa que não é várias coisas é necessariamente uma coisa numericamente e, consequentemente, é coisa singular. (OCKHAM 1978, p. 12, lin. 70-80; EPor. Prooem., § 2) ${ }^{19}$.

A coisa é numericamente uma e singular na medida em que, existente, é sempre a mesma. Quando aquecida, a mesma matéria deixa de ser parte do ar (frio) para ser parte do fogo (quente) ${ }^{20}$. Algo proporcional deve se dar com a essência. Mesmo que posta em vários homens, se há algo tal qual a humanidade, ela terá de ser, de algum modo, numericamente uma e sempre a mesma para todos os homens. Ainda estamos, portanto, diante da tese geral de que tudo aquilo que existe é singular. A referência ao intelecto separado de Averróis parece mostrar como essa "alteridade" da essência com relação às coisas nas quais ela existe pode ser dada: "ser geralmente em diversos ou com diversos ou sob diversos não faz nada que não seja numericamente um enquanto não for um e outro".

Que essa seja a função do argumento do Comentador aparece de modo mais claro no texto da Ordinatio, no qual ele é apresentado de forma um pouco mais contextualizada. Ali, a opinião combatida por Ockham é a seguinte:

Há, quanto a essa questão [sc. "se o universal é coisa verdadeira fora da alma”], uma opinião de que qualquer universal unívoco é certa coisa existente

\footnotetext{
${ }^{19}$ Hoc patet per exemplum. Quantumcumque materia eadem numero sit primo in aere, et pars eius, et postea in igne, et pars ignis, quia tamen non est alia et alia materia, ideo est una materia numero ; ergo eodem modo, si humanitas ista quae ponitur universalis, quantumcumque esset in pluribus hominibus, si tamen non esset alia et alia, vere esset una numero. Similiter secundum intentionem Commentatoris, quia non est alius intellectus in te et in me, ideo secundum eum est unus numero, ita quod generaliter esse in diversis vel cum diversis vel sub diversis nihil facit quin sit unum numero, dummodo non sit aliud et aliud; et ita omnis res quae non est plures res necessario est una res secundum numerum et per consequens est res singularis.

${ }^{20}$ Em Ockham, argumento semelhante aparece nas discussões sobre o movimento: cf. OCKHAM 1985, p. 457 s., lin. 2-44; EPhys. III, cap. 3, § 3 e OCKHAM 1985b, p. 505 s., lin. 206-232; EPhys. VI, cap. 6, § 2.
} 


\begin{abstract}
fora da alma realmente em qualquer singular e sobre a essência de qualquer singular, distinta realmente de qualquer singular e de qualquer outro universal, de modo que o homem universal é uma coisa verdadeira fora da alma existente realmente em qualquer homem e é distinta realmente de qualquer homem e do animal universal e da substância universal, e assim quanto a todos os gêneros e espécies, sejam subalternos ou não subalternos. E assim, segundo esta opinião, tantos são os universais predicáveis quanto à definição e no primeiro modo de por si a algum singular por si no gênero, tantas são nele as coisas realmente distintas das quais qualquer uma é realmente distinta da outra e daquele singular. E todas essas coisas (de nenhum modo multiplicadas em si mesmas por mais que os singulares sejam multiplicados) são em qualquer indivíduo da mesma espécie. (ОСКНАM 1970, p. 100, 1. 17-p. 101, lin. 11; Ord. I, d. 2, q. 4) $)^{21}$.
\end{abstract}

A posição, classificada por alguns como representando um "realismo grosseiro"22, defenderia a "inerência real do universal no singular e a distinção real entre universal e singular: o universal é uma coisa intrínseca e essencial às realidades singulares às quais

21 Ad istam quaestionem est una opinio quod quodlibet universale univocum est quaedam res exsistens extra animam realiter in quolibet singulari et de essentia cuiuslibet singularis, distincta realiter a quolibet singulari et a quolibet alio universali, ita quod homo universalis est una vera res extra animam exsistens realiter in quolibet homine, et distinguitur realiter a quolibet homine et ab animali universali et a substantia universali; et sic de omnibus generibus et speciebus sive subalternis sive non subalternis. Et ita secundum istam opinionem quot sunt universalia praedicabilia in quid et per se primo modo de aliquo singulari per se in genere tot sunt in eo res realiter distinctae quarum quaelibet realiter distinguitur ab alia et ab ilio singulari, et omnes illae res in se nullo modo multiplicatae, quantumcumque singularia multiplicentur, sunt in quolibet individuo eiusdem speciei. Em seu texto, Ockham aponta que essa opinião teria sido atribuída por alguns a Duns Escoto, mas não indica que concorda com essa atribuição. Valcke (in OCKHAM 1978b, "Introduction", p. 40 s.), no entanto, dá como certo que Ockham esteja criticando aqui a opinião de Duns Escoto. Na sua interpretação de uma passagem do texto da EPor. relativo a essa discussão, ele escreve: “On remarque d'abord que si l'argumentation par laquelle Ockham rejette la composition scotiste est valable, cette mème argumentation devrait le conduire à rejeter comme contradictoire l'idée d'après laquelle l'essence d'un individu un serait déterminé par une structure hylémorphique réelle et dualiste, puisqu'il affirme précisément contre Duns Scot qu' 'une chose est une seule chose numériquement quand elle ne contient pas en elle une multitude de choses distinctes quelles qu'elles soient'. (Ch. I, par. 2).”. Essa sua interpretação, porém, já foi objeto de crítica em PANACCIO 1981, p. 320 s..

${ }^{22}$ A classificação das três versões do realismo criticadas por Ockham como "grosseiro", "sutil" e "tímido" parece original de ALFÉRI 1989, p. 47-57. LIBERA 1996, p. 394-397, declaradamente retoma dele essa distinção, mas prefere a "tímido", "mitigado", mesma opção de MüLLER 2012, p. 52 s.. PANACCIO 2010, p. 268, prefere, por sua vez, a classificação que opõe principalmente o realismo "radical" ou "exagerado" (isto é, o "realismo platônico") ao "moderado": "A distinção 2 da Ordinatio argumenta detalhadamente contra diversas variantes do realismo dos universais, mas sempre se trata apenas daquilo que hoje em dia chamamos de realismo moderado, que, efetivamente, põe os universais fora da alma, mas que geralmente não os enxerga como substâncias e que, sobretudo, não os considera como separados das coisas sensíveis.". No entanto, MICHON 1994, p. 385, n. 4, aponta a compatibilidade dessas classificações: "Je reprends les catégories historiographiques d'ALFERI 1989 (bien que les trois réalismes puissent être considérés comme appartenant à la catégorie du réalisme modéré, que l'on oppose traditionnellement au réalisme absolu que serait le platonisme : aucun des trois ne soutient la thèse d'une subsistance de l'universel indépendante des individus)." Seja como for, todos parecem concordar em que a posição criticada em Ord. I, d. 2, q. 4 se resuma à defesa da existência de um universal fora da alma ainda que, embora delas realmente distinto, não separado das coisas sensíveis. 
é comum e realmente distinto delas." (MüLLER 2012, p. 52). Essa opinião defende exatamente a mesma tese que é criticada quando, no texto da EPor., é citada a autoridade de Averróis sobre a unidade do intelecto. Mas para que isso fique evidente, talvez não seja suficientemente claro sustentar que o universal seja realmente distinto das coisas às quais é comum, como sugere Müller na passagem que acabamos de mencionar. Afinal, que, naquilo que é uno por si, algo possa ser realmente distinto, mas não separado, é, por exemplo, o que cabe ao próprio composto:

Quanto a esses cumpre saber que, às vezes, o Comentador fala propriamente sobre a composição, e assim apenas $o$ indivíduo que tem várias [partes] é composto, quer na alma, quer fora da alma. (OCKHAM 1984, p. 772, 1. 31 ss.; QPhys., q. 138) ${ }^{23}$.

No composto de matéria e forma, que existe realmente fora da alma, embora a matéria e forma sejam coisas realmente distintas entre si, elas não são senão o mesmo que o composto, ou seja, elas formam um único indivíduo singular, que é uno por si:

Cumpre notar que quando o Filósofo diz que a forma não é separada da matéria senão segundo a razão e o Comentador diz no comentário 12 que a forma 'é separada da matéria apenas por definição', eles não pretendem dizer que a matéria e a forma são uma única coisa, distintas apenas segundo a razão e a definição. $\mathrm{O}$ que eles têm a intenção de dizer é que a forma não é separada da matéria de modo a poder ser sem a matéria, como o Comentador diz naquele mesmo lugar. Mas elas são duas coisas realmente distintas mesmo que a matéria não possa ser despida de toda forma de modo a ser sem a forma... (OСКНАм 1985, p. 248, lin. 87-94 EPhys. II, cap. 2, § 4. Grifos nossos.) ${ }^{24}$

Diversamente do que acontece com a matéria e a forma (que, no final, acabam sendo o mesmo que o composto enquanto suas partes), o universal que é uma coisa existente fora da alma nos singulares, mas realmente distinta deles, é considerado numericamente uma coisa para todos eles:

\footnotetext{
${ }^{23}$ Pro istis sciendum est quod aliquando Commentator loquitur de compositione proprie, et sic solum individuum quod habet plures [partes] est compositum vel in anima vel extra animam.

${ }^{24}$ Quarto notandum est quod quando dicit Philosophus quod forma non separatur a materia nisi secundum rationem et Commentator dicit, commento 12, quod forma 'est separata a materia secundum definitionem tantum', non intendunt quod materia et forma sint una res et distincta tantum secundum rationem et definitionem, sed intendunt quod forma non est separata a materia ita quod possit esse sine materia, sicut dicit Commentator ibidem. Sed tamen sunt duae res distinctae realiter quamvis materia non possit denudari ab omni forma ita ut sine forma... Que a matéria e forma façam o uno por si: "Ainda, se [sc. a essência e o ser] fossem duas coisas, ou fariam o uno por si ou não. Se fizessem, seria preciso que um fosse ato e o outro potência; e, consequentemente, um seria matéria e o outro forma, o que é absurdo." - Item, si essent duae res, aut facerent per se unum aut non. Si sic, oporteret quod unum esset actus et reliquum potentia; et per consequens unum esset materia et aliud forma, quod est absurdum. (OCKHAM 1974, p. 553, lin. 13 ss.; SL III-II, cap. 27. Grifo nosso.).
} 


\begin{abstract}
Se for dito do segundo modo, $\mid \S$ a saber, que ela [sc. "a coisa universal"], não variada nem multiplicada em si, é comunicada a muitos e permanece realmente distinta deles, $\S \mid$ tal comunicabilidade ou existência em muitos não exclui a unidade numeral, [...] porque, segundo a ficção do Comentador, embora o intelecto possível seja em muitos homens, ainda assim é numericamente um porque é realmente distinto de qualquer um deles e não é multiplicado em si por mais que os homens aos quais se une sejam multiplicados, portanto, do mesmo modo, se não for multiplicado em si, mas unicamente forem multiplicados os homens singulares nos quais é, por mais que aquele homem comum, que se sustenta ser realmente distinto, seja em muitos homens singulares dos quais, sejam quais forem, é realmente distinto, ele será absolutamente um numericamente. (OCKHAM 1970, p. 111, 1. 12-15.19-p. 112, lin. 6; Ord. I, d. 2, q. 4$)^{25}$.
\end{abstract}

$\mathrm{O}$ argumento do intelecto separado visa mostrar que, embora existente em vários, o universal não se diversifica nesses vários, tal como acontece, por exemplo, com a matéria e a forma: o universal não é multiplicado em si, mas são multiplicados unicamente os homens singulares nos quais ele é. O texto de Averróis serve, portanto, para modalizar a interpretação do modo segundo o qual o universal existe em vários: o universal não existe em vários tal como a matéria e a forma, isto é, sendo parte deles. Existir em vários (ou diversos) passa a poder ser entendido tanto como existir com diversos ou sob diversos. Em outras palavras, sendo numericamente uma coisa, o universal não pode existir enquanto tal nos indivíduos: ele é realmente distinto de qualquer um deles e, de fato, separado deles. Desse modo, entender a existência em muitos como comunicabilidade preserva a unidade numérica do universal: ainda que seja em vários homens, o universal não se multiplica em si mesmo, já que, multiplicando-se, já não seria mais um universal, mas parte dos próprios indivíduos nos quais existe.

Em suma, a primeira tese metafísica defendida a respeito dos universais é, na verdade, uma tese geral a respeito de toda coisa que possa ser dita existente: todo existente é, desde si, sem qualquer adição, uma coisa singular e numericamente uma. Os argu-

\footnotetext{
${ }^{25}$ Si dicatur secundo modo, $\mid$ \$ scilicet quod ipsa non variata in se nec multiplicata communicatur multis et distincta remanet realiter ab illis, $\$ \mid$ talis communicabilitas vel exsistentia in multis non excludit unitatem numeralem; [...] quia, secundum fictionem Commentatoris, quamvis intellectus possibilis sit in multis hominibus nihilominus est unus numero quia distinguitur realiter a quocumque illorum, nec multiplicatur in se quamvis homines quibus unitur multiplicentur; igitur eodem modo, quamvis ille homo communis, qui ponitur distingui realiter, sit in multis hominibus singularibus a quorum quolibet distinguitur realiter, si tamen in se non multiplicetur, sed solum homines singulares in quibus est multiplicentur, erit simpliciter unus numero.
} 
mentos de autoridade que Ockham seleciona para serem apresentados em seguida dessa argumentação "pela razão" não aparecem senão em função de reafirmar essa tese:

Isso também fica claro pela autoridade do Comentador no comentário 29 de Metafísica VII, em que diz assim: "não pode haver demonstração sobre o particular, mesmo que, quanto à verdade da coisa, apenas ele seja ente". Portanto, segundo o Comentador, unicamente o particular, quanto à verdade da coisa, é ente, portanto, todo ente é particular. De modo semelhante, no mesmo lugar, o comentário 44 diz assim: "Quando (acrescente: Aristóteles) declarou que estes que as definições significam são as substâncias das coisas e que as definições são compostas dos universais que são predicados aos particulares, começou a investigar se os universais são as substâncias das coisas ou unicamente as substâncias particulares às quais aqueles universais são predicados; e isso foi necessário para a declaração de que as formas da substância dos indivíduos são substâncias e que, no indivíduo, não é substância senão a matéria e a forma particular das quais ele é composto". Dessa autoridade fica claro que não há nenhuma coisa no indivíduo que não a matéria particular e a forma particular. Ora, toda coisa imaginável ou é o indivíduo e, assim, certamente é singular, ou é no indivíduo e essa não é senão a matéria particular e a forma particular, portanto, qualquer coisa é singular e particular. (ОсКНАм 1978, p. 12 s., lin. 81-98; EPor. Prooem., § 2) ${ }^{26}$.

Assim, Ockham mostra que, nos textos sobre a metafísica, mesmo se enunciada de modo diverso, temos reafirmada fundamentalmente a mesma tese defendida pela razão: todo ente é particular. Também mostra que, ainda neles, aparece claramente afirmada a impossibilidade de o universal ser tomado como algo existente no indivíduo: no indivíduo, não há senão a matéria e a forma particulares das quais ele é composto ${ }^{27}$.

E assim, apenas no encerramento da discussão dessa primeira tese, Ockham volta ao caráter "imaginável" da coisa, que até então havia sido deixado de lado: toda coisa

\footnotetext{
${ }^{26}$ Hoc etiam patet per auctoritatem Commentatoris VII Metaphysicae, commento 29, ubi dicit sic: "De particulari non potest esse demonstratio, quamvis ipsum tantum sit ens in rei veritate". Ergo secundum Commentatorem tantum particulare est ens in rei veritate; ergo omne ens est particulare. Similiter ibidem, comento 44, dicit sic: "Cum declaravit, supple Aristoteles, quod ista quae significant definitiones sunt substantiae rerum, et definitiones componuntur ex universalibus quae praedicantur de particularibus, incepit perscrutari utrum universalia sint substantiae rerum, vel tantum substantiae particulares de quibus praedicantur ista universalia; et hoc est necessarium in declarando quod formae individuorum substantiae sunt substantiae, et quod in individuo non est substantia nisi materia et forma particularis ex quibus componitur". Ex ista auctoritate patet quod nulla res est in individuo nisi materia particulares et forma particularis. Sed omnis res imaginabilis vel est individuum, et ita certe est singularis, vel est in individuo et talis non est nisi materia particularis et forma particularis; igitur quaelibet res est singularis et particularis.

${ }^{27}$ Que a substância particular não seja senão precisamente o indivíduo, vê-se em OCKHAM1974, p. 120, lin. 75-78; SL I, cap. 42: "a substância particular que existe fora da alma não significa este algo, mas ela é significada: portanto, Aristóteles chama aqui 'substância primeira' o nome da substância particular que existe fora da alma" - substantia particularis exsistens extra animam non significat hoc aliquid, sed ipsa significatur; igitur primam substantiam vocat hic Aristoteles nomen substantiae particularis exsistentis extra animam. Os grifos são nossos.
} 
(existente) imaginável, isto é, toda coisa existente que pode ser, de algum modo, pensada, ou é o indivíduo ou é no indivíduo, ou seja, ou é exatamente o singular, ou é a matéria particular e a forma particular, o composto que é numericamente um. Se existe, o universal é uma coisa singular sem qualquer adição: que nada tem adicionado a si nem é adicionado a outro.

\section{b.) Não há um universal existente fora da alma:}

Diversamente do que aconteceu com a defesa da primeira tese ou conclusão, a segunda conclusão aparece desde o início sustentada pelos textos das autoridades. Como vimos, segundo ela, "não há um universal existente realmente fora da alma nas substâncias individuais, nem desde a substância ou desde a essência delas.”. Se compararmos o modo segundo o qual essa conclusão é aqui apresentada com o texto paralelo da Ordinatio (OCKHAM 1970, p. 237, lin. 19-p. 239, lin. 15; Ord. I, d. 2, q. 7), veremos que o interesse de Ockham na EPor. não vai além de elencar três argumentos que ele propõe se seguirem dos textos aristotélicos por ele citados.

Segundo o primeiro deles,

1.) O universal não é substância, nem parte da substância, nem realmente na substância (cf. OCKHAM 1978, p. 13, lin. 99-109; EPor. Prooem., § 2).

A princípio, esse argumento não parece ir muito além do que já fora afirmado pela última autoridade citada na conclusão da argumentação sobre [a]: "no indivíduo, não é substância senão a matéria e a forma particular das quais ele é composto" (AvERRóIS 1562, f. 92vb; In Metaph. VII, cap. 10). Afinal, uma vez que não há fora da alma outra substância que a substância particular que é o próprio singular composto de matéria e forma, parece óbvio que, não sendo nem o singular material, nem matéria, nem forma, o universal não pode ser nem substância, nem parte dela, nem nela. Segundo a interpretação que Ockham faz de Metafísica VII (cap. 13, 1038b 7-9), Aristóteles entenderia que o universal não é uma substância, nem parte dela, nem uma coisa existente realmente na substância, porque entenderia o universal como causa máxima e princípio do ser das substâncias. No entanto, não há quanto à autoridade de Aristóteles, ou seja, quanto ao 
texto de Aristóteles que vemos citado amparando essa conclusão, qualquer análise que vise explorar em que sentido o universal é dito "causa máxima e princípio do ser das substâncias". A autoridade é apenas tomada quanto a seu valor de face: sendo causaetc. das substâncias, o universal não pode ser a própria substância causada. O mesmo procedimento se repete quanto à segunda conclusão tirada dos textos de Aristóteles, a saber,

2.) Os universais, os gêneros, assim como o ente comum, não são substâncias nem partes das substâncias (cf. OCKHAM 1978, p. 13 s., lin. 110122; EPor. Prooem., § 2).

Do modo como aparece enunciada, essa segunda conclusão não faz mais do que ampliar ou explicitar o alcance do que é defendido na conclusão anterior. Nos textos citados, os gêneros são explicitamente apontados como universais, donde, consequentemente, não poderiam nem ser substâncias nem partes delas etc. É interessante notar que, de acordo com o modo segundo o qual os textos são citados, o ente entra nessa lista não exatamente por ser do mesmo modo um universal, mas por partilhar uma característica com o universal que é tal predicável - o fato de que ambos são, de algum modo, "comuns"28: "Dado que os universais não são substâncias, é manifesto que o ente comum não é substância existente fora da alma, de modo que um comum não é substância”. A terceira conclusão, que é tirada dos mesmos textos usados como base para a segunda conclusão, especialmente do trecho do Comentário de Averróis (AvERRóIS 1562, f. 120rb; In Metaph. X, cap. 4) que acabamos de reproduzir sobre o ente comum, finalmente defende a impossibilidade de uma existência exterior à alma dos universais:

3.) os universais não são senão unicamente na alma e não na coisa exterior (cf. OCKHAM 1978, p. 14, lin. 123 s.; EPor. Prooem., § 2).

Assim, na exposição da conclusão [b], mais do que o enunciado de uma nova tese, temos mais propriamente o resultado (/conclusão) do princípio anteriormente enunciado quando aplicado aos universais. Se tudo o que existe é singular e, se nos indivíduos que

\footnotetext{
${ }^{28}$ Como se vê na conclusão do capítulo que analisamos, “... Ora, a delimitação desses universais deve ser tomada assim: tomandopor 'universal' aquilo que é predicado a muitos e não a todos, pelo que se exclui o 'ente'." - Sed suficientia istorum universalium sic accipi debet; et hoc accipiendo 'universale' pro illo quod praedicatur de pluribus, et non de omnibus, per quod 'ens' excluditur. (OCKHAM 1978, p. 16, lin. 195-198; EPor. Prooem., § 2)
} 
existem fora da mente, nada há além da matéria e da forma particulares, nesses singulares exteriores não há nada que possa ser referido, fora da mente, como um universal: não existindo fora da mente, resta ao universal que exista na alma.

Encerrada essa parte da discussão, fica claro, enfim, por que razão Ockham entendeu que as questões propostas por Porfírio são questões metafísicas e não de lógica: todas elas supõem, em última instância, a existência (esse) do universal e, nessa medida, caem sob o princípio metafísico fundamental da singularidade de todo existente.

\title{
3.) A solução de Ockham para as questões de Porfírio.
}

- $\quad 1^{a}$ Questão: o gênero e a espécie são subsistentes fora da alma ou são unicamente no intelecto?

Tendo encerrado a discussão prévia que defendia a singularidade de todo existente, Ockham passa à sua resposta do questionário da Isagoge. E começa afirmando que o gênero e a espécie são unicamente no intelecto:

\begin{abstract}
Os gêneros e as espécies não são subsistentes fora da alma, mas são unicamente no intelecto, porque não são senão certas intenções ou conceitos formados pelo intelecto que exprimem as essências das coisas e que as significam e não são elas mesmas, assim como o signo não é seu significado. E não são partes das coisas - não mais do que a voz é parte do seu significado -, mas são certos predicáveis para as coisas: não por si, porque quando o gênero é predicado à espécie, o gênero e a espécie não supõem por si porque não supõem simplesmente, mas pessoalmente e, assim, supõem por seus significados que são as coisas singulares. Ora, tais gêneros e espécies são predicados às coisas pelas próprias coisas que significam, assim como em "Sócrates é animal", "animal" não supõe aí por si, mas supõe pela coisa, a saber, pelo próprio Sócrates. (OCKHAM 1978, p. 14, lin. 130-141; EPor. Prooem., § 2). ${ }^{29}$
\end{abstract}

Os gêneros e as espécies são intenções ou conceitos que exprimem as essências das coisas e que significam as coisas, mas que não são as próprias coisas. Eles expri-

\footnotetext{
29 quantum ad primam quaestionem, tenendum est quod genera et species non sunt subsistentia extra animam, sed tantum sunt in intellectu, quia non sunt nisi quaedam intentiones vel conceptus formati per intellectum exprimentes essentias rerum et significantes eas, et non sunt ipsae, sicut signum non est suum significatum. Nec sunt partes rerum, non plus quam vox est pars sui significati; sed sunt quaedam praedicabilia de rebus, non pro se, quia quando genus praedicatur de specie, genus et species non supponunt pro se quia non supponunt simpliciter, sed personaliter, et ita supponunt pro suis significatis quae sunt res singulares; sed ista genera et species praedicantur de rebus pro ipsis rebus quas significant. Sicut in ista, 'Sortes est animal', li 'animal' non supponit pro se, sed supponit pro re, puta pro ipsomet Sorte.
} 
mem as essências na medida em que as compõem, tal como aparece no texto da Reportatio:

toma-se a quididade pela definição composta de conceitos diversos, do gênero e da diferença. E essa quididade não é realmente o mesmo com aquilo de que é quididade, porque ela apenas tem ser objetivo na alma e, de nenhum modo, subjetivo. (OCKHAM 1984b,p. 263, lin. 18-21; Rep. IV, q. 13) ${ }^{30}$.

Não nos interessa, aqui, a discussão sobre a existência subjetiva ou objetiva do conceito do universal, mas o fato de que a essência da coisa não é tomada por Ockham, nesse caso, como sendo mais do que a definição que o intelecto forma a partir da apreensão de algo. A essência não é tomada, portanto, como uma forma distinta da coisa da qual é essência, tal como, segundo o próprio Ockham, pode bem ser o caso em outros $\operatorname{contextos}^{31}$. Mas, Ockham acrescenta, embora sejam conceitos ou intenções das coisas que significam as próprias coisas, os gêneros e as espécies não são as próprias coisas. Parece óbvio que, como o próprio Ockham sugere, aqui não tenhamos muito mais do que a reiteração de que "o signo não é seu significado". Mas, de fato, isso não é tudo. A ênfase no fato de que embora o gênero e a espécie signifiquem as coisas, eles não sejam as próprias coisas também indica que, embora eles não sejam partes das coisas, eles significam as coisas enquanto predicáveis a elas. Com essa observação, Ockham parece querer evitar uma interpretação da suposição semelhante àquela que, na Suma de Lógi$c a$, ele diz ser defendida por alguns "ignorantes":

Segue-se daí que seja falso o que alguns ignorantes dizem: que o concreto, da parte do predicado, supõe pela forma, isto é, que em 'Sócrates é branco', 'branco' supõe pela brancura. Pois, seja como for que os termos suponham,

30 Tertio modo accipitur quidditas pro defmitione composita ex diversis conceptibus generis et differentiae. Et illa quidditas non est idem realiter cum eo cuius est, quia illa solum habet esse obiectivum in anima et nullo modo subiectivum.

${ }^{31}$ Cf. OCKHAM 1984b, p. 263, lin. 12-17; Rep. IV, q. 13: "De outro modo toma-se a quididade pela forma última pela qual algo é distinto de qualquer outro que não seja o mesmo com ele. E é verdadeiro sobre a quididade assim tomada que a quididade difere daquilo de que é quididade e que, nos separados da matéria, a quididade é o mesmo com aquilo de que é quididade, porque aquilo é simples, não tendo alguma distinção intrínseca a partir das partes intrínsecas." - Alio modo accipitur quidditas pro forma ultima qua aliquid distinguitur ab omni alio quod non est idem cum illo. Et de quidditate sic accepta est verum quod quidditas differt ab eo cuius est quidditas, et quod in separatis a materia est idem quidditas cum eo cuius est, quia illud est simplex, non habens aliquam distinctionem intrinsecam ex partibus intrinsecis. 

39-39; SL I, cap. 63) $)^{32}$

Assim, embora signifiquem as coisas tal como aquilo que é a elas predicado (e não propriamente como o termo que, numa proposição, exerce a função de sujeito), o gênero e a espécie não significam nada distinto das próprias coisas, como uma forma, nem, consequentemente, são apenas partes das coisas, como aquilo que nelas existe, assim como dizemos que a matéria e a forma são lexistem no composto. Os gêneros e as espécies são, portanto, signos das coisas que a elas são predicados quando declaram sua essência ou definição. Subsistentes no intelecto como intenções ou conceitos, são, ainda, signos naturais.

\title{
- $2^{a}$ Questão: o gênero e a espécie são corporais ou incorporais?
}

Ockham não aponta o caráter natural do signo mental senão quando explicitamente trata do caráter convencional dos signos falados ou escritos. Com efeito, como uma "última observação" a respeito da primeira questão, Ockham escreve o seguinte:

\begin{abstract}
Contudo, ainda que (segundo a intenção dos filósofos e segundo a verdade) aqueles que são no intelecto sejam gêneros e espécies, no entanto, além deles, as próprias vozes correspondentes podem ser de algum modo chamadas gêneros e espécies, na medida em que tudo aquilo que é significado pela intenção ou conceito na alma é significado pela voz e vice-versa. Isso, no entanto, não se dá senão pela convenção daquele que institui. (OCKHAM 1978, p. 14 s., lin. 142-147; EPor. Prooem., § 2) $)^{33}$.
\end{abstract}

As vozes, ou seja, as palavras, faladas ou escritas, impostas para significar o mesmo que a intenção ou o conceito na alma significam, também podem, de algum modo, serem chamadas elas mesmas gêneros ou espécies. Assim, apenas num sentido muito lato poder-se-ia dizer que os gêneros e as espécies subsistem fora da alma, ou seja, enquanto nada mais são que as palavras faladas ou escritas. Mas, obviamente, esse não é um sentido relevante para a discussão da segunda questão de Porfírio: em última instân-

\footnotetext{
${ }^{32}$ Ex quo sequitur quod falsum est, quod aliqui ignorantes dicunt, quod concretum a parte praedicati supponit pro forma; videlicet quod in ista 'Sortes est albus' li albus supponit pro albedine, nam haec est simpliciter falsa 'albedo est alba', qualitercumque termini supponant.

${ }^{33}$ Verumtamen quamvis ista quae sunt in intelectu, secundum intentionem philosophorum et secundum veritatem, sint genera et species, tamen praeter ista ipsae voces correspondentes possunt aliquo modo genera et species appellari, pro quanto omne illud, quod significatur per intentionem vel conceptum in anima, significatur per vocem, et e converso. Hoc tamen non est nisi ad placitum instituentis.
} 
cia, os universais não são esses signos convencionais, mas os signos naturais "que não são senão na mente, na qual não há algo corporal."34. É preciso notar, porém, que o conceito universal não é dito um signo natural exatamente pelo fato de que está na alma. Ele é dito natural porque significa a muitos por sua própria natureza e não por uma imposição. Nesse sentido, também uma voz [que, por não ser o resultado de uma imposição, aqui não poderia ser tomada corretamente como sinônimo de "palavra"] poderia ser dita um signo natural:

Donde dizem que a intelecção com a qual intelijo o homem é signo natural dos homens, tão natural quanto o gemido é signo da enfermidade ou da tristeza ou da dor... (OCKHAM 1974, p. 53, lin. 81 ss.; SL I, cap. 16. O grifo é nosso. $)^{35}$.

- $3^{a}$ Questão: se forem incorporais, o gênero e a espécie são separados dos sensíveis ou são nos próprios sensiveis?

Como resposta para a terceira questão, Ockham retoma algumas passagens do comentário de Averróis para o texto aristotélico de Metafísica VII que já haviam sido indicadas como as autoridades que defenderiam a tese de que todo ente é singular, em [a] (cf. supra, nota 26):

eis o quão manifestamente o Comentador quer que os universais não sejam partes das substâncias nem sejam desde a essência das substâncias, mas que unicamente declarem a substância das coisas, assim como os signos declaram seus signados e, por isso, não são eles, pois deve haver a distinção entre o signo e o signado. (OCKHAM 1978, p. 15, lin. 158-162; EPor. Prooem., § 2$)^{36}$.

Assim, subsistindo como intelecções e, portanto, sendo incorpóreos, os gêneros e as espécies nem são separados dos sensíveis nem são nos próprios sensíveis. As razões pelas quais não se pode dizer que os gêneros e as espécies não são nos sensíveis parecem já ter ficado suficientemente claras. No entanto, não parece que Ockham esteja

\footnotetext{
${ }^{34}$ Cf. OCKHAM 1978, p. 14 s., lin. 142-147; EPor. Prooem., § 2: "Desses é patente a solução da segunda questão, porque, não se falando das vozes, deve ser sustentado que os gêneros e as espécies (e, de modo geral, todos esses universais) não são corporais, porque não são senão na mente, na qual não há algo corporal." - Ex istis patet solutio secundae quaestionis, quia non loquendo de vocibus tenendum est quod genera et species, et universaliter omnia talia universalia, non sunt corporalia; quia non sunt nisi in mente, in qua non est aliquid corporale.

35 "Unde dicunt quod intellectio qua intelligo hominem est signum naturale hominum, ita naturale sicut gemitus est signum infirmitatis vel tristitiae seu doloris...”.

36 "Ecce quam manifeste vult Commentator quod universalia non sunt partes substantiarum nec sunt de essentia substantiarum, sed tantum declarant substantiam rerum, sicut signa declarant sua signata, et ideo non sunt ipsa, quia inter signum et signatum debet esse distinctio.".
} 
dizendo em sua resposta simplesmente que os gêneros e as espécies são separados dos sensíveis porque são intelecções deles, o que certamente é o caso. Mas Ockham também parece apontar em sua resposta não haver lugar para se entender os gêneros e as espécies como qualquer essência existente fora da alma: os universais declaram as substâncias das coisas e, nesse sentido, apenas podem ser signos. Já não há, como em Boécio, qualquer espaço para a discussão de uma subsistência dos universais que não seria mental e ainda assim seria "para além dos corpos". Para Ockham, por sua própria natureza, o universal não é senão aquilo que é predicável a muitos (cf. OCKHAM 1978, p. 15 s., lin. 163-198; EPor. Prooem., § 2).

Assim, ao fazer do universal nada além de um signo mental natural que não cumpre senão a função linguística de um predicado, Ockham elimina qualquer possibilidade de uma saída platonizante relativa à questão dos universais. Mas o que faria de Sócrates, Platão, Aristóteles etc., igualmente homens?

Segundo Michon (1994, p. 490),

O intelecto humano - que apreende as coisas e forma os conceitos que, por sua extensão, dependem delas, ainda que elas não dependam dele - descobre uma universalidade que ele não introduziu. Nem as coisas, que são singulares. Consequentemente, se sustentamos de uma só vez que

a) unicamente um conceito, ou uma palavra, pode ser universal (universale),

b) a universalidade do conceito humano (universale post rem) é posterior às e dependente das coisas,

c) as coisas se assemelham em virtude de um fundamento da semelhança (universale in re),

é preciso concluir em favor da existência de conceitos anteriores às coisas e dos quais elas dependeriam (universale ante rem). Será preciso, então, um outro intelecto [...] criador, arquetípico, que presta contas da inteligibilidade metafísica das coisas. E serão necessárias ideias divinas que tenham uma consistência própria, que não se reduzam a seus objetos.

Como se vê, Michon defende como uma consequência incontornável de um nominalismo tal qual o ockhamiano que as ideias divinas tenham de ser o fundamento dessa semelhança, tal qual o universale ante rem aviceniano. Mas defende também que Ockham teria montado suas teses de um modo falho, circular (cf. ibidem, p. 484), pois, em seu comentário ao texto agostiniano do De ideis (OCKHAM1979, p. 479-507; Ord. I, d. 35, q. 5), as teria montado de modo que nem é possível conceder a essa consequência nem é possível dar uma resposta coerente à questão da semelhança: 
De fato, é certo que há criaturas que são espécies: são os conceitos humanos. E se pensamos no conhecimento que Deus tem dos pensamentos humanos, poderemos falar nesse sentido do conhecimento divino das espécies. Em todos os casos verifica-se [sc. em Ockham] a tese de que 'as ideias são unicamente (praecise) dos singulares, uma vez que unicamente os singulares são criáveis'. É, portanto, evidente que esse conhecimento divino das espécies não funda nossos conceitos e, ainda menos, a co-especificidade dos indivíduos, mas as segue. (MICHON 1994, p. 481).

Michon parece ter razão em seu diagnóstico de que não há em Ockham uma resposta que indique algo como um universale ante rem a justificar a semelhança capaz de organizar os indivíduos em gêneros e espécies. No entanto, não é tão claro que sua defesa da necessidade desses universais como ideias divinas e da insuficiência da resposta de Ockham a respeito da questão do fundamento da semelhança desses indivíduos, peça central de seu livro, precise estar correta. A esse respeito, ainda parece ser necessário levar em conta, como o aponta Muralt (1993, p. 255) e, depois, Fernández (2010, p. 201 s.),

a expressão [...] do privilégio metafísico exclusivo da vontade na criação divina, do privilégio absoluto da onipotência divina, que produz imediatamente suas criaturas e as conhece unicamente no momento em que ela as produz: $i l$ las aspicit in producendo.... 


\section{BIBLIOGRAFIA:}

Fontes Primárias:

AVERRÓIS. Aristotelis opera cum Averrois Cordubensis commentariis, vol. VIII: Aristotelis metaphysicorum libri XIIII cum Averrois in eosdem commentariis et epitome, Theophrasti metaphysicorum liber. Venetiis apud Junctas, 1562. [= ed. Iuntina].

BoÉCIO. In Isagogen Porphyrii Commenta. Corpus Scriptorum Ecclesiasticorum Latinorum, vol. 48. Vindobonae: F. Tempsky/ Lipsiae: G. Freytag 1906 [= Ed. 1 ${ }^{\mathrm{a}}$; Ed. $\left.2^{\mathrm{a}}\right]$.

GUILHERME DE OCKHAM. Expositionis in Libros Artis Logicae Proemium et Expositio in Librum Porphyrii de Praedicabilibus. With a Preface by the editor. E. A. Moody (ed.). St. Bonaventure (NY): The Franciscan Institute, 1965.

. Scriptum in Librum Primum Sententiarum (Ordinatio). (Dist. II et III). S. Brown, ad laborante G. Gál (eds.). [= G. de Ockham Opera Theologica II] St. Bonaventure (NY): The Franciscan Institute, 1970.

. Summa logicae. P. Boehner, G. Gál e S. Brown (eds.). [= G. de Ockham Opera Philosophica I]. St. Bonaventure (NY): The Franciscan Institute, 1974.

.Expositionis in Libros Artis Logicae Proemium et Expositio in Librum Porphyrii de Praedicabilibus. E. A. Moody (ed.). Expositio in Librum Praedicamentorum Aristotelis.G. Gál. (ed.). Expositio in Librum Perihermenias Aristotelis. A. Gambatese \& S. Brown (eds.). Tractatus de Praedestinatione et de Praescientia Dei Respectu Futurorum Contingentium. P. Boehner \& S. Brown (eds.). [= G. de Ockham Opera Philosophica II]. St. Bonaventure (NY): The Franciscan Institute, 1978.

Commentaire sur le Livre des Prédicables de Porphyre, précédé du Proême du Commentaire sur les livres de l'art logique. Introduction de Louis Valcke. Traduction française de Roland Galibois. Sherbrooke : Centre d'Études de la Renaissance, Université de Sherbrooke, 1978b.

. Scriptum in Librum primum sententiarum (Ordinatio). (Dist. XIXXLVIII) G. I. Etzkorn et F. E. Kelley (eds.). [= G. de Ockham Opera Theologica IV] St. Bonaventure (NY): The Franciscan Institute, 1979.

. Quodlibeta Septem. J. C. Wey (ed.).[= G. de Ockham Opera Theologica IX]. St. Bonaventure (NY): The Franciscan Institute, 1980.

Brevis Summa Libri Physicorum. Summula Philosophiae Naturalis et Quaestiones in Libros Physicorum Aristotelis. S. Brown (ed.). [= G. de Ockham Opera Philosophica VI]. St. Bonaventure (NY): The Franciscan Institute, 1984.

Quaestiones in Librum quartum sententiarum (Reportatio). R. Wood et G. Gál, adl. R. Green (eds.). [= G. de Ockham Opera Theologica VII]. St. Bonaventure (NY): The Franciscan Institute, 1984b.

Expositio in libros Physicorum Aristotelis. Prologus et libri I-III. W. Richter e G. Leibold (eds.). [= G. de Ockham Opera Philosophica IV]. St. Bonaventure (NY): The Franciscan Institute, 1985. 
. Expositio in libros Physicorum Aristotelis (Libri IV-VIII). R. Wood, R. Green, G. Gál, J. Giermek, F. E. Kelley, G. Leibold, G. I. Etzkorn (eds.). [= G. de Ockham Opera Philosophica V]. St. Bonaventure (NY): The Franciscan Institute, 1985 b.

Estudos:

ADAMS, M. MC. William Ockham: Volume I. Indiana: University of Notre Dame Press, 1987.

ALFERI, P.. Guillaume d'Ockham. Le singulier. Paris: Minuit, 1989.

ANDRÉS, T. de. El nominalismo de Guillermo de Ockham como Filosofia del Lenguaje.Madrid:Gredos, 1969.

BIARD, J.. Guillaume d'Ockham. Logique et philosophie. Paris : PUF, 1997.

GILSON, E.. History of Christian Philosophy in the Middle Ages. New York: Random House, 1955.

FERNÁNDEZ, C. J.. Guilherme de Ockham: contra a ideia como exemplar. Discurso. Revista do Departamento de Filosofia da USP, vol. 40. São Paulo: Departamento de Filosofia da USP, 2010, p. 183-206.

LIBERA, A. de. La querelle des universaux. De Platon à la fin du Moyen Âge. Paris : Seuil, 1996.

. L’art des généralités. Théories de l'abstraction. Paris: Aubier, 1999.

MichON, C.. Nominalisme. La théorie de la signification d'Occam. Paris :Vrin, 1994.

Moody, E.A.. The Logic of William of Ockham. New York: Sheed\& Ward Inc., 1935.

Müller, P.. La logica di Ockham. Milano: Vita e Pensiero, 2012.

Muralt, A. DE. La métaphysique occamienne de l'idée in MurALT, A. DE. L'enjeu de la Philosophie Médiévale. Leiden, New York, Köln: Brill, 1993, deuxième tirage, p. 168255.

PANACCIO, C.. Le commentaire de Guillaume d'Occam sur le livre des prédicables de Porphyre, introduction par Louis Valcke ; traduction française par Roland Galibois. Dialogue. Vol. 20, issue 02, June 1981, p. 318-334.

. Guilherme de Ockham e a perplexidade dos platônicos. Tradução: Rodrigo Guerizoli. Discurso. Revista do Departamento de Filosofia da USP, vol. 40. São Paulo: Departamento de Filosofia da USP, 2010, p. 261-286. [Originalmente publicado em 1993].

PICHE, D.. Le problème des universaux à la Faculté des Arts de Paris entre 1230 et 1260. Paris: Vrin, 2005.

SPADE, P. V. (ed.).The Cambridge Companion to Ockham. Cambridge: UP, 1999. 